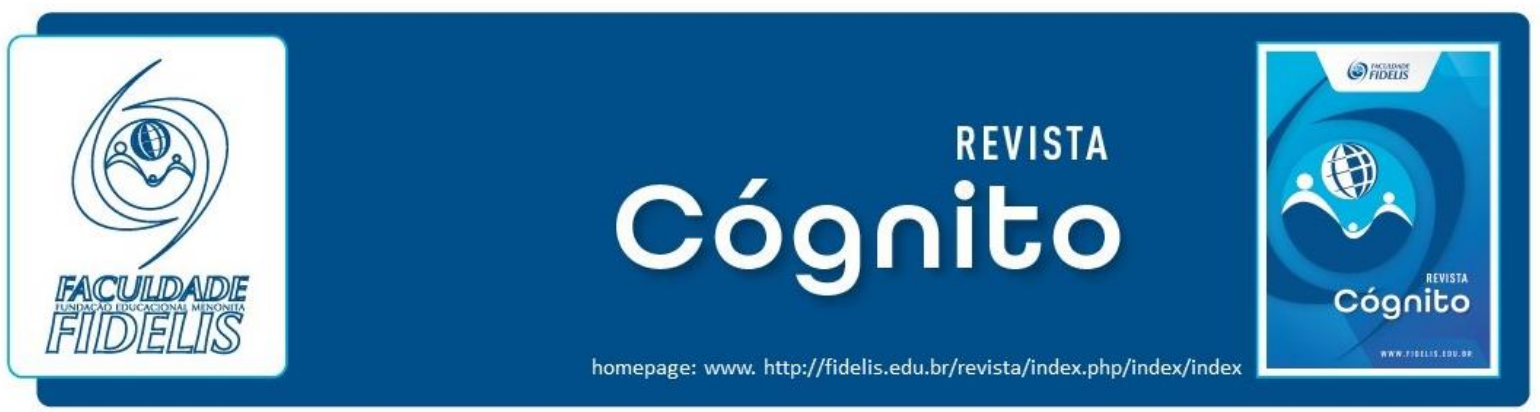

\title{
A BASE BÍBLICA PARA O ENVOLVIMENTO DO CRISTÃO NA POLÍTICA EM UM ESTADO LAICO
}

\author{
Nilton Abrão 1 \\ Arthur Wesley Dück²
}

\section{RESUMO}

O objetivo deste artigo é analisar a base bíblica para o envolvimento do cristão na política na condição constitucional atual do Brasil: laicidade. Qual a postura mais prudente que um cristão deve tomar em relação ao governo? De pesquisa exclusivamente bibliográfica, esse trabalho apresenta a relação Estado e Religião estabelecida por constituição no Brasil, expõe a relação Estado e Religião no Antigo Testamento, recorre a personagens que atuaram politicamente em contexto pagão e analisa princípios contidos no Novo Testamento. Embora seja possível atuar politicamente sem se corromper, entende-se que é melhor adotar a postura da fiscalização e profecia frente ao Estado.

Palavras-chave: Cristão e Política; Estado e Religião; Bíblia e laicidade.

\begin{abstract}
The purpose of this article is to analyse the biblical basis for the political involvement of the Christian in politics, in particular given Brazil's present situation: a lay country. What stance is appropriate for a Christian with respect to the government? The research was bibliographic and presents the State / Religion relationship established by the Brazilian constitution. The article also develops the State / Religion relationship in the Old Testament, with some biblical characters that were politically active in pagan context and analyses the principles for political involvement in the New Testament. Though it is possible to the involved politically without being corrupted by the system, the author deems it be to adopt an evaluative and prophetic stance toward the State.
\end{abstract}

Key-word: Christian and politics; State/Religion; Bible and Lay State

\section{INTRODUÇÃO}

Este artigo tem por objetivo analisar a base bíblica para o envolvimento do cristão na política no Brasil na condição de Estado laico. Para isso pretende-se primeiramente analisar a relação de religião e Estado no Brasil, depois averiguar a relação de religião e Estado na Bíblia,

\footnotetext{
${ }^{1}$ Bacharel em Teologia pela Faculdade Fidelis. niltontal@gmail.com>.

${ }^{2}$ Bacharel em Teologia pela Faculdade Fidelis; Mestrado em Divindade - Trinity Evangelical Divinity School (EUA), Doutorado em Estudos Interculturais - Trinity International University (EUA). Docente no curso de Teologia da Faculdade Fidelis
} 
para então recorrer a personagens que atuaram na política do Antigo Testamento e extrair conceitos políticos no Novo Testamento.

A pesquisa será exclusivamente bibliográfica. Recorre-se a autores como Souza (2009) e Oro (2011) para verificar a relação entre Estado e Igreja no Brasil. Gusso (2003), Caragounis (2012) e Smith (2001) auxiliam na definição do conceito Reino de Deus e na relação entre Estado e Religião na Bíblia. Baldwin (1983) e Freston (1990) são utilizados para a análise de personagens que atuaram na política no AT. Para a política do NT, oferecem auxílio autores como Stott (2007), Morris (1983) e Osborne (2014).

$\mathrm{O}$ autor desse trabalho convive com duas posições opostas quanto ao envolvimento da igreja cristã na política: um que opta pela omissão, não se contaminando pela corrupção e outro que se envolve, mas onde muitos se corrompem. Convivendo com esses dois extremos, desejase saber qual a posição sugerida biblicamente. Parte-se sob a hipótese de que a igreja está no contexto como fiscalizadora do Poder que Deus deu ao homem.

\section{A RELAÇÃO RELIGIÃO E ESTADO NO BRASIL}

Este trabalho se restringe a estudar a base bíblica para o envolvimento do cristão na política do Brasil em sua condição atual. Por isso, julga-se necessário, antes de analisar a posição bíblica, primeiramente conhecer a relação políticoreligiosa em vigor no Brasil.

"Durante todo o período colonial (1500-1822) e imperial (1822-1889), o catolicismo foi a única religião legalmente aceita, não havendo liberdade religiosa em nosso país" (ORO, 2011, p. 224-225). Souza informa que após a transição do regime monárquico para republicano no país, houve a formalização da separação entre Religião e Estado, através do "Decreto 119- A, do dia 7 de janeiro de 1890". Entre outras providências desse decreto, Souza destaca a proibição da intervenção da autoridade federal e dos Estados federados em matéria religiosa, a consagração da plena liberdade de cultos e a extinção do padroado (2009, p. 198). Já Oro, além da extinção do regime do padroado e a garantia da liberdade religiosa para todos os cultos, ainda ressalta com o fim do monopólio católico a secularização dos aparelhos estatais, do casamento e dos cemitérios (2011, p. 225).

Ao averiguar a situação legal atual de vinte e sete países pertencentes à União Europeia e de vinte países latino-americanos, Oro identifica três formas de laicidade possível: (1) separação Estado-Igreja; (2) separação Igrejas e Estado com dispositivos particulares em relação a algumas religiões ou igrejas; (3) Igrejas de Estado (2011, p. 222). Para ele, trata-se 
de três tipos de laicidade, porque, independentemente das formas de relações entre Estado e Igrejas, "predominam, em todos os países referidos, em graus diferenciados, os princípios da liberdade religiosa e de cultos, da não discriminação religiosa por parte do Estado e da separação entre poder político e poder religioso." O Brasil, segundo ele, "figura entre os onze países latinoamericanos e os sete países europeus que adotaram o regime jurídico da separação entre Igreja e Estado." (2011, p. 224).

Souza afirma que constitucionalmente o Brasil continua a ser um Estado Laico (2009, p. 210):

\begin{abstract}
A sexta Constituição republicana, promulgada no dia 05 de outubro de 1988 e atualmente em vigor, manteve o princípio da separação entre Religião e Estado no Brasil. a ideologia da laicidade está consagrada no artigo 19, inciso I, da Constituição Federal. Segundo a cláusula constitucional, é vedado à União, aos Estados, ao Distrito Federal e aos Municípios "estabelecer cultos religiosos ou igrejas, subvencioná-los, embaraçar-lhes o funcionamento ou manter com eles ou seus representantes, relações de dependência ou aliança, ressalvada, na forma da lei, a colaboração de interesse público". (SOUZA, 2009, p. 209).
\end{abstract}

Embora Oro e Souza apresentem o Brasil como sendo teoricamente laico, ambos concordam que na prática a situação é controversa. Depois de expor alguns eventos onde o catolicismo foi privilegiado, Oro conclui que "a pretensa neutralidade do Estado em relação à religião, subentendida na noção de separação entre o poder temporal e o espiritual, constitui mais um ideal do que uma realidade." (2011, p.

229). Semelhantemente, Souza afirma que "os atos e os fatos que envolvem Religião e Brasil revelam que a autenticidade entre a teoria e a prática da separação entre Religião e Estado está distante do ideal pretendido pelos jusfilósofos da laicidade.” (2009, p. 210).

Enfim, apesar do contraste entre o ideal e a realidade, pode-se afirmar que a laicidade, ao menos teoricamente, está em vigor no Brasil. Partindo da separação entre Igreja e Estado formalizada por lei no Brasil, recorrer-se-á a Bíblia para examinar qual a postura política que um cristão deve tomar na situação de separação entre Igreja e Estado.

\title{
2 RELIGIÃO E ESTADO NA BÍBLIA
}

Reconhecendo a separação entre Estado e Religião por constituição no Brasil, quer-se agora sucintamente recorrer à relação de ambos na Bíblia. Para isso, recorre-se primeiramente ao significado de ambos os termos. Segundo o Dicionário Priberam da Língua Portuguesa, o 
termo Estado significa "Nação considerada como entidade que tem governo e administração particulares" e o termo Religião,

“Comunidade religiosa que segue a regra do seu fundador ou reformador" (2015). Partindo desses significados, entende-se que só é possível haver alguma forma de relação entre Estado e Religião na Bíblia, quando há a existência de ambos. Por isso, averiguar-se-á o nascimento da nação de Israel.

Mesmo ciente de que há divergências sobre a data de início da nação israelita, Gusso (2003, p. 21) entende que "isto aconteceu no momento em que Deus, utilizando Moisés como intermediário, estabeleceu um pacto com eles

[israelitas], três meses depois que saíram do Egito (Êx 19)”. Pois, a partir desse momento, “deixavam de ser um aglomerado de pessoas ou de clãs, sem muitas ligações, como eram, e passavam a ser um estado, ainda que não nos moldes modernos, organizado em torno de seu rei exclusivo: Iavé".

Nos primeiros dois séculos de existência, a nação israelita não teve nenhum governo humano central, pois vivia sob o "Sistema de Governo Teocêntrico" (cf.

GUSSO, 2003, p. 21-22, 39-41). Gusso (2003, p. 40) lembra que "não havia nada que pudesse lembrar ou sugerir uma administração estatal organizada. Os clãs, ou tribos, permaneciam independentes, unidos apenas pelo vínculo religioso".

Isso ocorre até o término do período dos Juízes, quando Israel substitui o sistema de governo, recorrendo à monarquia (cf. $1 \mathrm{Sm} \mathrm{8)}$. Apesar de ter surgido uma crise no conceito da teocracia sobre Israel com o surgimento da figura de um rei, Caragounis, recorda que a situação de certa forma se normalizou com a ascensão de Davi, quando "o entendimento foi que o rei governava como representante de Javé e estava sob suserania divina. Ouseja, via-se a monarquia como a manifestação concreta do governo de Javé". Ele acrescenta que "o reino davídico foi de certa forma fundido com o governo de Javé” (2012, p. 1062).

Concordando com Caragounis, pode-se afirmar que mesmo na fase monárquica, Israel ainda entendia estar sob a teocracia. Keller, ao caracterizar Israel como um governo teocrático, lembra que violações religiosas, como idolatria e adultério, eram punidas pelo estado (2013, p. 41). Em outras palavras, uma vez que o rei deveria ser estabelecido por Deus (cf. Dt 17.14-20) e ser o seu representante sobre a terra, as decisões dele deveriam estar em sintonia com as leis de Deus e consequentemente com a vontade de Deus. Para que isso se tornasse realidade, ele deveria fazer uma cópia do livro da lei e ler nele todos os dias. Só assim temeria o Senhor e agiria em sintonia com ele (Dt 17.18-20). Ações do rei Josias caracterizam essa teocracia: ele 
ordenou, por exemplo, aos sacerdotes que retirassem os utensílios que foram feitos para outros deuses do templo de Jerusalém e ao povo que celebrasse a Páscoa (2Rs 23.4,21), também matou sacerdotes idólatras (2Rs 23.20).

Vendo a nação israelita que a manifestação concreta do governo de Deus sobre Israel ocorria no período da monarquia davídica, pode-se entender que "boa parte da esperança de Israel para o futuro está ligada à sorte nacional e política da nação" (SMITH, 2001, p. 386). E esta expectativa continua mesmo após a divisão da nação israelita em dois reinos (cf. 1Rs 12), e após estes perderem o governo de suas terras nas guerras contra a Assíria (cf. 2 Rs 17) e a Babilônia (cf. 2Rs 25).

Smith afirma que "Israel esperava a restauração da liberdade do domínio estrangeiro e a recuperação da terra e da prosperidade perdidas" (SMITH, 2001, p. 386-387):

\begin{abstract}
A esperança de restauração nacional e política de Israel incluía a derrota dos opressores [...], a restauração da dinastia e do reino de Davi [...], a unificação dos dois reinos [...], o retorno do exílio [...], purificação religiosa e moral [...], a reconstrução do templo e um sacerdócio purificado [...], fertilidade paradisíaca da terra [...], do povo e do gado [...], transformação dos animais selvagens [...], exaltação de Sião [...], um novo rei $[\ldots]$, conhecimento universal de Deus [...] e paz universal [...]. (SMITH, 2001, p. 387).
\end{abstract}

Para Smith (2001, p. 387-388), “essas expectativas do Antigo Testamento não incluíam nada que não pudesse ser cumprido neste mundo". Ele afirma, sem hesitação, que "a maioria dos judeus e dos cristãos no primeiro século esperava que o reino de Deus fosse estabelecido na terra. Até os discípulos perguntaram a Jesus, depois da sua ressurreição, quando ele restauraria o reino a Israel (At 1.6)". Stott nota que os discípulos estavam esperando um reino político e territorial; [...] um reino nacional; e [...] uma restauração imediata” $(2008$, p. 40).

Sendo assim, pode-se afirmar que, de forma geral, em seu entendimento, a nação israelita uniu os conceitos Reino de Israel e Reino de Deus. Enquanto a nação existia como reino, via-se a mesma como estando debaixo da suserania de Deus. Quando foi dominada por outras nações, via-se na volta da liberdade israelita também a volta do Reinado de Deus. De certa forma, via-se Israel, no AT, tanto como sendo o povo de Deus, como também sendo um Estado, por isso também a mistura de ambos os conceitos.

Pelo fato do interesse desse trabalho estar na postura do cristão num Estado constitucionalmente separado de uma religião oficial, não será analisada a postura política de personagens bíblicos que viviam sob a teocracia. Ou seja, levando em conta que o nascimento 
da nação de Israel ocorreu a partir do pacto firmado entre os israelitas e Deus, sob a intermediação de Moisés, não serão analisadas posturas políticas nas fases de Juízes e da Monarquia. Serão analisados personagens que não viveram no período em que a nação de Israel vivia sob a suserania divina.

Embora a concepção generalizada até a época de Jesus fosse a mistura dos conceitos Reino de Israel e Reino de Deus, é necessário reconhecer que a separação desses conceitos já se encontra no Antigo Testamento. Para Caragounis, “o conceito de Reino de Deus apresentado por Daniel é transformado sob o impacto da nova situação". Ele comenta que "Daniel não apenas apresenta o reino de Deus despido de sua natureza davídica, terreno e política, mas também descreve seu agente como um ser celeste e transcendental” (2012, p. 1062). Assim como posteriormente no ensino de Jesus, em Daniel esse agente é “o Filho do homem” (2012, p. 1070).

Quem aparece na condição de Filho do homem é a "pessoa de Jesus" (CARAGOUNIS 2012, p. 1069). Pode-se assim afirmar que o agente do Reino de

Deus é Jesus. Para Keller "a famosa lição de Jesus sobre 'dai a César o que é de César, e a Deus o que é de Deus' (Mt 22.21) assinalou que a igreja e o Estado não eram mais uma única instituição" (2013, p. 41). Grudem, usando a mesma passagem, vai além, entendendo que "Jesus mostra que devem existir dois âmbitos distintos de influência, um para o governo, outro para a vida religiosa do povo de Deus". Isso significa que a igreja não deve tentar controlar coisas que dizem respeito ao governo civil, como impostos. E, em contrapartida, o governo civil não deve tentar controlar coisas que dizem respeito à vida religiosa das pessoas $(2014$, p. 28):

\footnotetext{
Na declaração de Jesus a respeito de Deus e de César, ele definiu os contornos mais amplos de uma nova ordem na qual "o que é de Deus" não deve estar sob controle do governo civil ("o que é de César"). Esse sistema é muito diferente da teocracia que governava o povo de Israel no antigo Testamento. O novo ensinamento de Jesus sugere que todos os governos civis, inclusive os de hoje, devem dar liberdade no tocante à fé religiosa que as pessoas escolhem seguir ou não, às doutrinas religiosas que adotam e ao modo como adoram a Deus. (GRUDEM, 2014, p. 29)
}

Caragounis, afirma que Jesus estava solidamente firmado no Antigo Testamento em sua proclamação do reino de Deus. "No entanto, Jesus tomou esse conceito e o transformou, fazendo que deixasse de ser uma esperança nacionalista cristalizada" e se tornasse uma nova ordem em que Deus é o rei, "uma ordem espiritual e universal em que a humanidade 
encontrasse o cumprimento dos desejos últimos que acalenta: retidão, justiça, paz, felicidade, liberdade do pecado e da culpa e um relacionamento restaurado com Deus” (2012, p. 1076).

Assim sendo, embora reconhecendo que já no Antigo Testamento há a visão de uma separação entre o estado e o reino de Deus, conclui-se que com o ensinamento de Jesus ambos, definitivamente deixam de ser sinônimos. Havendo a separação desses conceitos, surge a pergunta: qual a posição que o povo pertencente àquele deve tomar quanto a este? Para isso, analisar-se-á, primeiramente dois personagens do Antigo Testamento que agiram politicamente fora da nação israelita, consequentemente também em meios onde não se reconhecia a suserania do Deus de Israel. Depois averiguar-se-á a visão neotestamentária da relação entre a igreja e o estado, quando ambos conceitos já foram separados.

\section{POSTURA POLÍTICA EM CONTEXTO PAGÃO NO ANTIGO TESTAMENTO}

O primeiro personagem a ser analisado é Daniel, "influente tanto no Império Babilônico como no Medo-Persa” (LUTER, 2005, p. 127). Ele é classificado por Baldwin (1983, p. 142) como um "bem-dotado conselheiro" que provou, em certos incidentes, "ser de grande utilidade ao governante". Daniel foi por Dario (rei medo) posto no cargo de presidente sobre os sátrapas (Dn 6.2). O segundo personagem é Neemias que, segundo Kidner (1983, p. 14) foi nomeado por Artaxerxes I como governador de Judá.

\subsection{DANIEL}

Daniel, segundo Millard (2008, p. 1174, 1182), pertencia à "nata da geração seguinte de Judá", tendo ao menos 12 ou 13 anos quando foi "desarraigado da sua terra natal" e "educado numa sociedade estrangeira". Baldwin (1983, p. 86) esclarece que essa "reeducação dos reféns", a qual Daniel agora fora submetido, "tinha o objetivo de prepará-los [...] para serviço real". Ela (1983, p. 87) também nota que Daniel agora teria de decidir a forma em que se ajustaria para viver num ambiente hostil a suas convicções religiosas. No contexto de uma mudança transcultural ele teria "de analisar as implicações dos princípios envolvidos em suas ações, e começar exatamente do mesmo modo como" pretendia continuar. Baldwin (1983, p. 88) acrescenta que "Daniel aceita a reeducação e um novo nome, levanta, porém o seu protesto em relação" à "comida provinda da mesa real".

Millard (2008, p. 1183) entende que Daniel não queria se contaminar "ao consumir comida sem consideração pela regulamentação israelita, com probabilidade de conter carnes declaradas imundas [...], possivelmente associadas a rituais pagãos”. Kroeker (1977, p. 55) 
afirma que Daniel escolheu substituir a comida real, por vegetais (cf. 1.12), sendo que estes, em seu entendimento, não eram oferecidos aos deuses. Baldwin (1983, p. 88), por sua vez discorda dos dois autores, afirmando que "toda a comida na Babilônia ou na Assíria era ritualmente impura (Ez 4.13; Os 9. 3,4) e não havia possibilidade de fugir disso.” Ela explica que:

\begin{abstract}
Pelos padrões orientais, compartilhar de uma refeição era se comprometer a uma amizade; tinha uma significação pactual (Gn 31.54; Êx 24.11; Ne 8.912; cf. Mt 26.2628). Assim, aqueles que tivessem se disposto a obedecer nessa questão aceitavam uma obrigação de lealdade ao rei. Pareceria, então, que Daniel tenha rejeitado este símbolo de dependência do rei porque queria estar livre para cumprir as suas obrigações prioritárias para com o Deus a quem servia. A contaminação que temia não era tanto de natureza ritual como moral, provinda da sutil adulação que representavam as dádivas e favores, que continham, bem no fundo, implicações de um leal apoio, não importando quão dúbias pudessem ser as futuras políticas de ação do rei. (BALDWIN, 1983, p. 88-89).
\end{abstract}

Sendo assim, mesmo ciente da divergência entre os autores, quanto a impureza ser ritual ou moral, pode-se afirmar que Daniel, em sua preparação ao serviço real, aceitou se submeter às ordens reais desde que as mesmas não ameaçassem a sua lealdade a Deus. Como a comida designada da própria mesa do rei poderia interferir na sua fidelidade a Deus, Daniel opta por abster-se da mesma.

Para Baldwin, caso essa informação chegasse a Nabucodonosor (rei da Babilônia), ele certamente interpretaria o motivo de permanecer livre de um compromisso com a vontade do rei como sendo traiçoeiro. Por correr o risco de ser culpado de cumplicidade, o chefe dos eunucos mostra-se relutante em atender ao pedido de Daniel, e quem o atende é um oficial de status inferior, o cozinheiro-chefe. Como o pedido de Daniel traria benefícios para este, também havia a garantia de que isso se manteria em segredo (BALDWIN, 1983, p. 89). Reconhece-se assim, que, por dar prioridade a lealdade a Deus, Daniel pôs-se sob risco de ser considerado pelo rei como traidor.

Luter (2005, p. 127) observa que "Daniel cresceu de forma notável, até ocupar posições nos mais altos escalões da autoridade imperial e ter influência tanto no Império Babilônico como no Medo-Persa, durante uma carreira que durou mais de 60 anos”. Millard (2008, p. 1174) entende que o que levou Daniel a tal posição de relevância foram "as suas habilidades e a integridade inspirada pela sua fé".

Baldwin identifica que tanto Nabucodonosor (Dn 4.8), como também a rainha 
(5.11) e Belsazar (5.14) afirmam que há a presença do "espírito dos deuses" em Daniel. O que se queria dizer, segundo ela, com essa expressão é que "Daniel era 'muito espiritual'." Ela também ratifica que "apesar da mudança de governo", no capítulo 6, "Daniel continuou sendo bem-visto e respeitado". (1983, p. 118-119,134). Isso pode ser confirmado em Daniel 6.2-5, onde se observa que Daniel fora encarregado de supervisionar, juntamente a outros dois homens, o serviço civil de todo o império, sendo ainda cogitada a sua promoção.

"Quando parecia que Daniel ia ser promovido, seus invejosos colegas planejaram um modo de levá-lo à morte" (BALDWIN, 1983, p. 134). Eles induziram o rei a aprovar uma lei que obrigava todos a dirigir orações ao imperador (HOUSE, 2005, p. 641), sendo que quem fizesse, no espaço de trinta dias, petição a qualquer deus ou homem, que não fosse o rei, seria lançado na cova dos leões (Dn 6.9).

Baldwin comenta que esse documento fez de Dario "rei-deus por trinta dias, conforme a lei dos medos e dos persas". Ela afirma que Daniel era irrepreensível em obediência à lei do país, sendo que só se encontraria nele motivos de acusação se a lei do seu Deus chegasse a conflitar com a lei do país (BALDWIN, 1983, p. 136).

Havendo novamente o conflito entre a lei divina e a lei do país, Daniel novamente opta por dirigir primeiramente a sua lealdade a Deus, consequentemente desobedecendo ao decreto do rei e sendo lançado na cova dos leões (Dn 6.10-18). Mas ele não age de forma a provocar seus inimigos intencionalmente. Ele continuou orando "como era o seu costume" (Dn 6.10). A sua morte não ocorreu, porque houve intervenção sobrenatural de Deus (Dn 6.22)

A história de Daniel, para House (2005, p. 642), e os demais acontecimentos registrados nos 6 primeiros capítulos do livro de Daniel indicam "que Israel pode permanecer fiel a Yahweh, ser útil aos seus dominadores e abençoado por ambos".

Destaca-se em Daniel que, mesmo levado para outro contexto, de um país que não reconhecia seu governo como sendo teocrático, e posteriormente, mesmo com mudanças da ordem do rei, ele continuou priorizando a fidelidade a Deus. Esta sua lealdade a Deus independia se ele se encontrava no período em que estava sendo instruído ao serviço imperial, ou se já estava ocupando funções imperiais. Exercendo estas, ele foi marcado por sua integridade e lealdade às leis imperiais, desde que as mesmas não conflitassem com suas convicções religiosas. Ele não tinha medo de ficar impuro, de se envolver com os poderes que se opuseram a Israel, mas se envolveu como influência positiva em meio a reinos autoritários. Quando as leis destes conflitavam com a lei divina, ele priorizava a lei divina, pondo em risco inclusive a sua vida. 


\subsection{NEEMIAS}

Neemias viveu no século seguinte a Daniel e foi um alto burocrata na Pérsia, o maior império da época (FRESTON, 1990, p. 7, 18). Antes de ser nomeado governador de Judá (Ne 5.14), ele era copeiro do rei Artaxerxes (Ne 1.11), o que lhe permitia constante acesso ao rei. Seu posto é classificado por Pratt (2005, p. 484), como sendo "de confiança", pois tinha "a tarefa de provar o vinho antes do rei beber, para garantir o seu não-envenenamento”. Além de provar o vinho, Walton, Matthews e Chavalas (2003, p. 487-488) destacam que o copeiro “era responsável pelo anel com o sinete real e o oficial-mor das finanças”. Segundo eles, pela importância da posição, acompanhada do acesso que a mesma permitia ao rei, o copeiro exercia grande influência.

Na função de copeiro, Neemias foi informado da situação deplorável de Jerusalém (Ne 1.3). Com "interesse imediato no bem-estar do povo e de sua cidade" (BARBER, 2011, p. 27), ele queria reedificar a cidade de Judá (Ne 2.5). Mas, como Freston lembra, Neemias precisava de outros para pôr o seu projeto em prática. Mais especificamente, ele dependia do rei (1990, p. 20). Se o fato de pedir licença do cargo que obtinha já seria difícil, mais complicado ainda seria pedir apoio real para a reconstrução do muro de Jerusalém, pois “Artaxerxes havia especificamente proibido [isso] anteriormente (Esdras 4.17-22).” (BARBER, 2011, p. 33).

Quatro meses após receber a notícia da situação de Jerusalém, Neemias, “contraria a etiqueta para oficiais da corte", demonstrando tristeza, atitude essa, provavelmente proposital: atrair a atenção real (FRESTON, 1990, p. 31). Pode-se assim afirmar que, após mostrar interesse pelo bem de seu povo, Neemias também toma a iniciativa de buscar ajuda. Com isso, Freston observa que Neemias, assim como Daniel, arrisca tudo, "mas com a diferença de que Neemias não está sendo moralmente obrigado a arriscar-se. Trata-se de uma iniciativa sua, e não de uma iniciativa imperial à qual é preciso resistir". De forma voluntária, Neemias "põe tudo a perder, a fim de conseguir uma licença para ir a Jerusalém.” (FRESTON, 1990, p. 18).

Notando a tristeza de Neemias, o rei lhe pergunta o motivo (Ne 2.2). Neemias então manifesta-lhe o seu interesse em ir à cidade de seus antepassados para reparar os danos (Ne 2.5-8). Barber (2011, p. 35) e Freston (1990, p. 31-32) observam nessa resposta, que Neemias havia se preparado anteriormente, conhecendo assim as suas necessidades. Kidner ainda destaca que qualquer atitude vaga por parte de Neemias, no inquérito do rei, "teria demonstrado que o projeto era um mero sonho ou impulso repentino; Neemias, porém, orara por tempo 
suficiente, para visualizar a operação com bastante detalhe, até mesmo a técnica da construção que empregaria no muro" (1985, p. 87-88).

O rei concorda com seu pedido e o deixa ir a Jerusalém (Ne 2.6). Lá, Neemias exerce a função de governador de Judá durante doze anos (Ne 5.14).

Nessa posição "ele tinha o direito de esperar o sustento do povo da província", mas propositadamente sustentava a si mesmo para não o sobrecarregar" (BARBER, 2011, p. 105). "Ele foi um exemplo de austeridade pessoal: abriu mão das regalias normais do cargo porque, nas circunstâncias, seria injusto exigi-las. Além disso, não aproveitou sua posição para enriquecer pessoalmente" (FRESTON, 1990, p. 60).

Destaca-se assim que Neemias, depois de já ter conquistado a confiança do rei, sendo seu copeiro, por interesse no bem-estar de seu povo, toma a iniciativa de buscar ajuda, arriscando assim tudo o que já havia conquistado. $\mathrm{O}$ bem-estar de seu povo que antes o motivou a arriscar tudo o que tinha, posteriormente também o levou a abrir mão das regalias a que tinha direito como governador (Ne 5.14-19).

Freston $(1990$, p. 20, 38) ainda comenta que "Neemias trabalhava numa corte extravagante que explorava a periferia, inclusive Judá”, mas que, mesmo aceitando a ajuda de um rei pagão, ele não se viciou nem se vendeu ideologicamente.

\section{VISÃO NEOTESTAMENTÁRIA DA RELAÇÃO ESTADO E IGREJA}

Como já verificado anteriormente, Jesus, o agente do Reino, cristaliza a separação do conceito Reino de Deus e Estado. "Enquanto os reinos terrenos são estabelecidos por exércitos e por poder militar, o reino de Jesus seria estabelecido pelo poder do evangelho que transforma o coração das pessoas a as leva a crer nele e lhe obedecer" (GRUDEM, 2014, p. 31). Consequentemente poder-se-á recorrer a ensinos de Jesus e também dos apóstolos, para compreender a concepção que o Novo Testamento fornece para a relação Igreja e Estado. Driver (1994, p. 123-124) entende que o texto de Lucas 22.25-27, seus paralelos Mateus

20.25-28 e Marcos 10.42-45, e similar João 13.12-17, "são ainda mais fundamentais para a visão neotestamentária da relação entre a igreja e o estado do que Romanos 13 e Apocalipse 13”. Por isso, analisar-se-á abaixo, primeiramente a contribuição do texto de Lucas (também seus paralelos e similar), para depois recorrer às passagens de Romanos e Apocalipse. 


\subsection{LUCAS 22}

Enquanto Mateus apresenta a mãe de Tiago e João solicitando a Jesus que seus filhos sentassem um a direita e outro a esquerda de Jesus em seu reino (Mt 20.20-21), Marcos relata que foram os próprios Tiago e João que fizeram esse pedido (Mc 10.35-37) e Lucas - em seu relato "similar [...], mas que, provavelmente, ocorre em uma situação distinta" (CARSON, 2010, p. 501) - limita-se a descrever uma discussão entre todos os discípulos sobre qual deles parecia ser o maior (Lc

22.24). Para Morris (1983, p. 288) é evidente que "os discípulos pensavam que estava perto o reino de Deus".

Como já fora apresentado no capítulo anterior deste artigo, mesmo depois de Jesus ter ressuscitado, os discípulos ainda esperavam que Jesus estabelecesse um reino político em Israel. Porém, como pode ser verificado agora (Mt 20.25; Mc 10.42; Lc 22.25), diferentemente da expectativa dos discípulos, Jesus, já antes de sua morte e ressurreição afirma que o reino de Deus é diferente do reino dos gentios.

Carson analisa a "ética de Jesus da liderança e do poder em sua comunidade de discípulos" como "revolucionária". Ele esclarece que, quem viria à mente com a expressão "gentios" ou "pagãos", neste caso, seriam os romanos, cujo império era caracterizado por poder e autoridade. Essa estrutura de "exercer domínio", não pode ser transferida "para o relacionamento entre seus seguidores. Grandeza entre os discípulos de Jesus baseia-se no serviço.” (CARSON, 2010, p.

$504)$.

Levando em conta que os discípulos esperavam que Jesus estabeleceria o Reino de Deus em Israel, é possível afirmar que eles, revogando uma posição de grandeza, provavelmente almejavam no reino de Deus o que os romanos, em estado de grandeza, recebiam em seus reinos: autoridade e poder. Entretanto Jesus não vincula o poder no Reino de Deus à grandeza, mas sim, o serviço.

Short explica que Jesus mostrou aos discípulos que "enquanto no reino dos homens o teste de grandeza está no número de pessoas que alguém consegue controlar [Mc 10.42], no seu Reino está no número de pessoas que alguém pode ajudar”. Ele entende que Jesus, com isso, "ressaltou que a mais alta honra a que um homem poderia aspirar não consiste em ocupar os postos principais dos reinos, mas em servir outras pessoas.” (2008, p. 1623).

Essa revolucionária mudança de estrutura sugerida por Jesus, do exercício de poder para a prestação de serviços, não somente implica na pergunta: “com que objetivo o cristão 
quer atuar politicamente?”, como também na dúvida se é necessário atuar politicamente para poder servir aos outros.

Carson (2010, p. 504) afirma que Jesus se apresenta "como o supremo exemplo de serviço para os outros". Para Driver, "tanto Mateus, quanto Marcos ressaltam que o caminho que cabe ao Ungido de Deus é 'dar sua vida em resgate por muitos'.” (1994, p. 125).

Se a vida de Jesus é o modelo de serviço, logo se julga também necessário analisar a sua opção de postura em relação ao estado, para assim enxergar uma possível resposta à dúvida da necessidade de atuar politicamente para praticar a prestação de serviços.

Driver enxerga que a primeira decisão que Jesus precisou "tomar em relação ao estado era se devia assumir o controle deste ou se devia utilizá-lo para realizar os propósitos de Deus no mundo". Recorrendo a Lucas 4.1-13, ele afirma que "basicamente, foi essa tentação satânica fundamental contra a qual Jesus lutou no começo e ao longo de seu ministério messiânico”. Sem hesitação, ele ratifica que essa decisão se deveu "a uma nova visão do caminho que há de tomar o homem de Deus no mundo". Ele finaliza "se Jesus renunciou à possibilidade de exercer o senhorio conforme os termos em que a autoridade é exercida no mundo, seus discípulos haveriam de renunciar também" (1994, p. 125).

\subsection{ROMANOS 13 E APOCALIPSE 13}

Os textos de Romanos 13.1-7 e Apocalipse 13, conforme Driver, costumam ser lidos através de lentes constantinianas. Sob essa perspectiva, o texto paulino está apresentando a ordem do Novo Testamento: que os cristãos "obedeçam às autoridades civis no exercício da força coerciva necessária na sociedade secular".

Elliott afirma que devido à licença que deram aos tiranos, "esses versículos causaram mais infelicidade e sofrimentos no Oriente e Ocidente cristãos do que qualquer outro conjunto de sete versículos no Novo Testamento" (2004, p. 184).

Para Stott, os três versículos iniciais de Romanos 13 apresentam uma ordem paulina de aplicação universal, que exige a submissão às autoridades e exorta contra a rebelião (2007, p. 411-415). Bruce enxerga no fato de Paulo apresentar Deus como a fonte de toda autoridade, a implicação da desobediência às autoridades também significar desobediência a Deus, por isso: “os cristãos de todas as nações devem obedecer às leis, pagar as taxas e respeitar as autoridades - não porque será pior para eles se não o fizerem, mas porque é um modo de servir a Deus" (1979, p. 189). Recorrendo ao contexto próximo e ao contexto geral dos escritos apostólicos, ele afirma que estes "esclarecem que o Estado tem direito de exigir obediência 
somente dentro dos limites dos propósitos para os quais foi instituído por Deus" e que "não só se pode, mas se deve resistir ao Estado quando este exige lealdade devida exclusivamente a Deus" (1979, p. 192).

Entretanto Elliott acredita ser pior universalizar Romanos 13.1-7 como uma teologia do Estado cristã, do que relativizar essa exortação, mesmo sendo contrário também a segunda possibilidade (2004, p. 185). Driver afirma que essa exortação paulina "não representa um resumo fundamental da atitude neotestamentária quanto ao estado" (1994, p. 124).

Para Stott a realidade do estado é bem diferente nos tempos em que Romanos e Apocalipse foram escritos. Para ele, quando João escreve, "o estado já não é mais visto como servo de Deus, detentor da autoridade divina, mas [...] um aliado do diabo [...] cuja autoridade foi conferida ao estado perseguidor”. Sua conclusão é que, embora ambas sejam verdadeiras, “Apocalipse 13 é uma paródia satânica de Romanos 13” (2007, p. 415).

Elliott, no entanto, entende que as afirmações de Paulo, considerando as autoridades servas de Deus, "são meros lugares comuns retóricos que pretendem" focalizar os membros da igreja no discernimento do bem, os impedindo, consequentemente, de criar problemas nas ruas. Para ele, as autoridades romanas estavam incluídas nas acusações que Paulo registra na carta sobre idolatria pagã

(Rm 1.18-23), paixões degradantes (Rm 1.24-27) e vícios (Rm 1.28-32). “A menção por Paulo de substituir a conduta 'vergonhosa' pela retidão (Rm 6 e 12) envolve claramente o cristão nas vicissitudes da vida pública: 'Não se amoldem às estruturas deste mundo'.”. Portanto, "para a interpretação [...] 'a exortação é decisiva', não as premissas sobre as quais Paulo fundou [...] a exortação.” (2004, p. 186-187).

A interpretação sob lentes constantinianas de Romanos 13.1-7 carece "de base bíblica" (DRIVER 1994, p. 124) e causou "mais sofrimentos [...] do que qualquer outro conjunto de sete versículos do Novo Testamento (ELLIOTT, 2004, p. 184)". Logo, esse texto não pode ser usado por um cristão em posição de autoridade para exigir submissão de outro cristão. "Só as mais perniciosas reviravoltas do destino iriam [...] arrolar esses versículos como estando a serviço do próprio Império" (2004, p. 202). Ciente disso, buscar-se-á, então desenvolver a interpretação da exortação de Paulo, sob as lentes dos destinatários da carta.

Dunn identifica que a mesma foi escrita aos cristãos de Roma. Não se sabe como o cristianismo iniciou lá. Mas a comunidade judaica era grande e havia "uma missão cristã ativa entre os da 'circuncisão' (G1 2.9)”. Sabe-se também “que muitos judeus foram expulsos de Roma, provavelmente em 49 d.C., por causa das 'agitações provocadas por Chrestus'” [...], 
sendo 'Chrestus' quase universalmente entendido como uma referência a Cristo". Portanto, "o cristianismo fincou pé em Roma no ambiente das muitas sinagogas de Roma". Em algum momento, nos anos iniciais os gentios foram, em algum momento, atraídos para a igreja de Roma" (2012, p. 1158).

Ou seja, o cristianismo em Roma era formado por judeus e gentios. Logo, a carta de Paulo aos Romanos estava destinada aos gentios-cristãos e judeus-cristãos de Roma. Para Dunn, o conhecimento da existência de tensões entre judeus e gentios, ajuda a explicar determinadas passagens, inclusive Romanos 13.1-7. Essas tensões foram provocadas devido à influência e ao menosprezo da comunidade judaica. "Ela era menosprezada, para não dizer odiada, pelas vozes mais influentes da intelectualidade romana", em parte, porque era uma comunidade grande, em parte pelo "tratamento preferencial que havia recebido de Júlio César e de Augusto e provavelmente o mais importante - ao número de gentios que eram atraídos para o judaísmo". (2012, p. 1158-1159).

\footnotetext{
Além disso, caso seja grande o número de judeus cristãos entre os que foram expulsos em 49 d.C., podemos ainda inferir que as igrejas romanas perderam boa parte de seus líderes e membros. Era previsível que a liderança dos gentios tivesse se tornado a regra. Depois que o decreto de Cláudio começou a perder força e os judeus cristãos começaram a voltar a Roma, é bem possível que tenham surgido algumas tensões entre os antigos e novos crentes. (DUNN, 2012, p. 1158).
}

É possível, assim deduzir, que além da tensão exterior, havia também uma tensão na igreja de Roma entre os gentios e judeus. Elliott constroi sua interpretação, sob a condição da carta se dirigir “ostensivamente a gentios" (2004, p. 188). Depois de apresentar correspondências temáticas entre Romanos 8 e 13 (cf. 2004, p.192) e de comparar a semelhança dos movimentos retóricos que percorrem os capítulos 8-11 e 12-15 de Romanos (cf. 2004, p. 191-195), ele afirma que

Paulo "pretende combater a arrogância gentio-cristã e evocar simpatia e solidariedade com Israel" (2004, p. 195).

A situação das comunidades judaicas era precária por todo o Império, inclusive em Roma, onde a comunidade judaica já sofreu expulsões sob Tibério e mais tarde sob Cláudio. “Os judeus corriam repetidos perigos devido à hostilidade de populações locais se a atenção de Roma fosse alienada ou retirada". Essa violência antijudaica não era provocada por diferenças religiosas, "mas por pressões sociais, especialmente a pressão da exploração e colonização romanas que as aristocracias helenísitcas desviavam para populações judaicas mais vulneráveis" (ELLIOTT, 2004, p. 190). 
Elliott acredita que "Paulo poderia muito bem ter esperado que os judeus de Roma recebessem o grosso da violência caso distúrbios relativos aos impostos viessem a eclodir na cidade" (2004, p. 191). Todo esse contexto sugere que Romanos 13.1-7 quer "simplesmente desviar os cristãos romanos da trajetória que os implicaria cada vez mais na transformação dos judeus em bodes expiatórios” (2004, p. 195). Nessa condição a função da exortação paulina seria de “estimular a submissão, então, às autoridades, em vez da resistência desesperada;" e, com isso "salvaguardar os mais vulneráveis em torno e no meio dos cristãos romanos, os judeus que lutavam por reconstruir sua comunidade abalada na esteira da violência imperial” (2004, p. 202).

Enquanto Elliott busca enfatizar sua análise textual na perspectiva dos cristãos gentios em Roma, Driver pressupõe seu significado para os cristãos judeus:

"não a solicitude de apoio incondicional por parte do cristão com respeito ao governo, mas o chamado a assumir uma postura não violenta ante um governo tirânico" (1994, p. 124).

Sendo assim, sob ótica de um cristão gentio, Romanos 13.1-7 significaria advertência "contra a arrogância, a presunção, a transformação dos fracos e vencidos em bodes expiatórios;" e também "advertência contra toda ação disruptiva que pudesse fazer recair sobre a comunidade pobre de Israel as ameaçadoras nuvens tempetuosas do poder imperial.” (ELLIOTT, 2004, p. 202). E, sob perspectiva de um cristão judeu, indicaria um chamado a se submeter à autoridade civil e não optar pelo uso da violência contra a mesma. Independente da condição "pelo fato de viverem na capital do império, os cristãos de Roma deviam se esforçar por cumprir as leis quanto fosse possível - inclusive pagando os impostos exigidos pelos romanos.” (DUNN, 2012, p. 1171).

A perspectiva constantiniana, volta a ter influência na interpretação de Apocalipse 13. Nessa condição, segundo Driver, o texto "costuma ser entendido como a descrição de um estado perverso contra o qual os cristãos devem rebelarse". Contrário a essa interpretação, ele alerta que, para o conceito de relação entre os cristãos e a autoridade civil, deve-se considerar o exemplo e os ensinamentos de

Jesus e assimilar o "caráter radicalmente diferente dessa 'guerra do cordeiro', que vence mediante a espada aguda que sai de sua boca e a paciência e a fé viva dos santos" (1994, p. 125).

Para Ladd (1980, p. 136), o texto apocalíptico "fala de duas bestas - uma que emerge do mar e outra que emerge da terra. A segunda serve a primeira. Seu único objetivo é obrigar 
os homens a adorar a primeira besta”. Osborne vê esse texto relatando a rebelião final de Satanás e que:

\footnotetext{
Para promover essa grande batalha contra Deus e seu povo, Satanás imita a Santa Trindade e estabelece a própria trindade falsa: o dragão (ele mesmo), a besta do mar (o Anticristo) e a besta da terra ou o falso profeta (o líder religioso do movimento). O dragão usa essas criaturas para ganhar o controle tanto do sistema político quanto do religioso, criando um único governo mundial (com o Anticristo como o "rei dos reis") e uma religião mundial (com o Anticristo como o ídolo do mundo). (OSBORNE, 2014, p. 568).
}

Ao analisar as implicações de Apocalipse 13, Osborne entende que o cristão não deve reagir passivamente, permitindo que o mal triunfe, mas "adotar uma postura profética e alertar os governantes acerca da loucura de suas ações". Isso, porém, deve ser feito "mediante a proclamação do evangelho, não da execução de um plano revolucionário para derrubar o governo." O não aderimento à idolatria, segundo as exigências éticas dos versículos 9 e 10, consiste em "aceitar em atitude pacífica" o aprisionamento e o martírio, colocando totalmente a confiança em Deus.

A fidelidade e a perseverança a quais João clama (v. 10b) “devem ser exemplificadas quando eles [os santos] se recusarem a agir contra as forças do mal e, em lugar disso, continuarem a se opor a elas mediante a proclamação do evangelho" (OSBORNE, 2014, p. 569-570).

Pode-se assim concluir que os textos de Romanos 13 e Apocalipse 13, diferentemente da concepção constantiniana, não foram escritos a serviço de um cristão em posição de autoridade, nem para encorajar uma revolução, mas para instruírem os cristãos a viverem como bom cidadãos em Roma e encorajá-los a perseverarem na fé.

\section{CONSIDERAÇÕES FINAIS}

Primeiramente foi vista a laicidade teórica do Brasil, motivo pelo qual buscou-se somente a base bíblica para atuação do cristão quando não há união Igreja e Estado. Por causa da situação constitucional do Brasil, não foram analisados personagens que agiram politicamente durante o período de juízes e período monárquico da nação israelita.

Os personagens bíblicos do Antigo Testamento analisados foram Daniel e Neemias, ambos tendo influência política em contexto pagão. Daniel passou por instruções antes de exercer funções imperiais e Neemias passou por uma fase de planejamento antes de reivindicar 
a reconstrução do muro de Jerusalém. Levando isso em consideração para a postura política em um estado laico, é possível concordar com Stott que “cristãos não deveriam se envolver" na política, "a menos que estejam preparados para desempenhar esse papel". Ele afirma que "política é coisa para políticos que já têm a experiência necessária" e que "não existe coisa mais embaraçosa do que ver um cristão dando palpites sobre questões políticas sem ter conhecimento do assunto" (2005, p. 390-391).

Além do período de preparação, ressalta-se que tanto Daniel como também Neemias não mudaram de atitude quando estavam em posição de poder. No caso de Daniel a sua fidelidade a Deus foi testada, e ele manteve a atitude de priorizar a lealdade a Deus sobre a lealdade ao estado. Para Neemias o conflito foi ideológico: pelo bem-estar do seu povo ele inicialmente arrisca todas as suas conquistas e posteriormente, diferentemente dos governos anteriores (Ne 5.15), ele se abstém das regalias governamentais. Essa atitude de Neemias é, conforme Grudem, um princípio bíblico: “o governo existe para benefício do povo, e não do rei, ou do imperador, ou do presidente" (2014, p. 122). Se antes foi visto que é necessário uma preparação para atuação em cargo político, agora se vê necessária averiguar a motivação que está por trás da decisão de agir no Estado: deveria ser o bem-estar do povo.

Embora Daniel e Neemias confirmem a possibilidade de atuar sem corrupção em cargos políticos no Estado, não se pode afirmar que haja necessariamente incentivo bíblico para agir no Estado. Viu-se que Jesus, o agente do Reino de Deus, escolheu exercer sua função, abdicando-se da relação com o Estado e orientou seus discípulos a servirem aos outros e não a imitarem a atitude dos imperadores, que exerciam domínio.

Mesmo não atuando no Estado, também se percebe que a postura cristã, quanto à cidadania deve ser exemplar: submetendo-se às autoridades (Rm 13), desde que não conflitam com as leis divinas. Em caso de confrontação, tomar postura pacífica, sem revolta, mas com ação profética. Grudem fornece vários exemplos bíblicos de pessoas tementes e fieis a Deus aconselhando governantes: Daniel aconselhando Nabucodonosor (Dn 4.27), João Batista repreendendo Herodes (Lc 3.19), Paulo arrazoando com o governador Félix (At 24.25). Ainda apresenta profetas do Antigo Testamento falando "a nações estrangeiras a respeito dos pecados delas". Essas repreensões proféticas são encontradas em "Isaías 13-23; Jeremias 46-51; Ezequiel 25-32; Amós 1-2; Obadias (a Edom); Jonas (a Nínive);

Naum (a Nínive); Habacuque 2; e Sofonias 2.” (2014, p. 45).

Conclui-se assim que, com base em exemplos de personagens bíblicos é possível se envolver politicamente num estado laico, sem se corromper. Para esse envolvimento torna-se 
necessária uma preparação anterior e ter como motivação o bem-estar do povo. Apesar dessa possibilidade, seguindo o exemplo de Cristo, seria mais prudente optar por não atuar na política do país, mas agir profeticamente, fiscalizando as atitudes estatais. Assim, confirma-se a hipótese inicial, e finaliza o artigo, afirmando que a postura mais prudente do cristão é observar e fiscalizar o Estado.

\section{REFERÊNCIAS}

BALDWIN, Joyce G. Daniel: introdução e comentário. São Paulo: Mundo Cristão e Vida Nova, 1983.

BARBER, Cyril J. Neemias e a dinâmica da liderança eficaz. 2. ed. São Paulo: Vida, 2011.

Bíblia sagrada Almeida Século 21: antigo e novo testamento. São Paulo: Vida Nova, 2008.

BRUCE, F. F. Romanos: introdução e comentário. São Paulo: Vida Nova, 1979.

CARAGOUNIS, C. C. Reino de Deus: Evangelhos. In: REID, Daniel G. (ed.). Dicionário teológico do Novo Testamento. São Paulo: Vida Nova, 2012, p. 10611077.

CARSON, D. A. O Comentário de Mateus. São Paulo: Shedd, 2010.

Dicionário Priberam da Língua Portuguesa. Disponível em:

$<$ http://www.priberam.pt/dlpo/>. Acesso em 16 de junho de 2015.

DRIVER, John. Contra a corrente: ensaios de eclesiologia radical. Campinas: Cristã Unida, 1994.

DUNN, J. D. G. Romanos, carta aos. In: REID, Daniel G. (ed.). Dicionário teológico do Novo Testamento. São Paulo: Vida Nova, 2012, p. 1157-1073.

ELLIOTT, Neil. Romanos 13.1-7 no contexto da propaganda imperial. In: HORSLEY, Richard A. Paulo e o império: religião e poder na sociedade imperial. São Paulo: Paulus, 2004, p. 184-202.

FRESTON, Paul. Neemias: Um Profissional a Serviço do Reino. São Paulo: ABU, 1990.

GRUDEM, Wayne. Política segundo a Bíblia: princípios bíblicos que todo cristãodeve conhecer. São Paulo: Vida Nova, 2014.

GUSSO, Antônio Renato. Panorama histórico de Israel: para estudantes da Bíblia. Curitiba: A. D. Santos, 2003.

HOUSE, Paul R. Teologia do Antigo Testamento. São Paulo: Vida, 2005.

KELLER, Timothy. Justiça generosa. São Paulo: Vida Nova, 2013.

KIDNER, Derek. Esdras e Neemias: introdução e comentário. São Paulo: Vida Nova, 1985. 
KROEKER, Jakob. Daniel: Staatsmann und Prophet. Alemanha: Brunnen-Verlag, 1977.

LADD, George. Apocalipse: introdução e comentário. São Paulo: Vida Nova, 1980.

LUTER, Boyd A. Daniel. In: GARDNER, Paul (Ed.). Quem é quem na Bíblia Sagrada. São Paulo: Vida, 2005, p. 123-128.

MILLARD, Allan R. Daniel. In: BRUCE, F. F. (Org.). Comentário Bíblico NVI: antigo e novo testamento. São Paulo: Vida, 2008, p. 1174-1208.

MORRIS, Leon L. Lucas: introdução e comentário. São Paulo: Vida Nova, 1983.

ORO, Ari Pedro. A laicidade no Brasil e no Ocidente: algumas considerações. Civitas. Porto Alegre, v.11, n.2, p. 221-237, mai-ago. 2011.

OSBORNE, Grant R. Apocalipse: comentário exegético. São Paulo: Vida Nova, 2014.

PRATT, Richard. Neemias. In: GARDNER, Paul (Ed.). Quem é quem na Bíblia Sagrada. São Paulo: Vida, 2005, p. 484-486.

SHORT, Stephen S. Marcos. In: BRUCE, F. F. (Org.). Comentário Bíblico NVI:

antigo e novo testamento. São Paulo: Vida, 2008, p. 1580-1693.

SMITH, Ralph L. Teologia do Antigo Testamento: história, método e mensagem. São Paulo: Vida Nova, 2001.

SOUZA, Josias Jacintho de. Separação entre Religião e Estado: utopia constitucional? Tese (Doutorado em Direito) - área de concentração Direito, Estado e sociedade, Pontífica Universidade Católica de São Paulo, São Paulo, 2009.

STOTT, John. A mensagem de Atos. São Paulo: ABU, 2008.

A mensagem de Romanos. São Paulo: ABU, 2007.

Ouça o Espírito, ouça o mundo. 2. ed. São Paulo: ABU, 2005.

Walton, John H.; MATTHEWS, Victor H; CHAVALAS, Mark W. Comentário bíblico Atos: Antigo Testamento. Belo Horizonte: Atos, 2003. 